\title{
POZITIVNI UČINCI KANABISA NA ZDRAVLJE
}

\author{
Maja Batori ${ }^{1}$, Ana Žerovnik ${ }^{1}$, Katarina Barać ${ }^{1,3}$, Dragan Babić C.,2,3 $^{12}$ \\ Filozofski fakultet Sveučilišta u Mostaru ${ }^{1}$ \\ Fakultet zdravstvenih studija Sveučilišta u Mostaru ${ }^{2}$ \\ Klinika za psihijatriju Sveučilišne kliničke bolnice Mostar ${ }^{3}$ \\ 88000 Mostar, Bosna i Hercegovina
}

Rad je primljen 29.8.2018. Rad je recenziran 13.9.2018. Rad je prihvaćen 28.9.2018

\section{SAŽETAK}

Kanabinoidi su aktivni sastojci jednogodišnje biljke koja se naziva indijska konoplja (lat. Cannabissativa). Kanabis (marihuana, konoplja) jedna je od najstarijih i najraširenijih biljaka poznatih čovjeku. Raste kao korov i kao uzgajana biljka diljem svijeta u raznim zemljama i klimama. Kemijski sastojci odgovorni za intoksikaciju i medicinsku djelotvornost nalaze se uglavnom u ljepljivoj zlatnoj smoli koju izlučuju cvjetovi na ženskim biljkama. Biljka kanabisa sadrži više od 460 poznatih sastojaka, među kojim ih više od 60 ima 21-ugljičnu strukturu tipičnu za kanabionide. Porijeklom iz središnje Azije, kanabis se uzgajao već prije deset tisuća godina, a u Kini su ga uzgajali 4000. godina pr.n.e. Kanabis je najrasprostranjenija i mladima najlakše dostupna ilegalana psihoaktivna tvar, koja se često razvrstava u kategoriju "lakih droga". Po međunarodnim klasifikacijama kanabinoidi spadaju u skupinu psihoaktivnih tvari koje mogu izazvati različite duševne i druge zdravstvene poremećaje. S druge strane nedvojbeno je dokazano da kanabis može imati i pozitivne učinke na ljudsko zdravlje. Medicinska konoplja sadrži sastojke koji posjeduju terapijska svojstva za velik broj ljudskih bolesti i fizičkih slabosti. Kanabis se propisuje za osobe oboljele od multipla skleroze radi zaustavljanja ili smanjivanja grčeva mišića, propisuje se oboljelima od AIDS-a i raka kako bi im se smanjila mučnina i potaknuo apetit. Primjenjuje i u liječenju epilepsije, depresije, tjeskobe i Alzheimerove bolesti. Kako bi učinkovitost kanabisa u liječenju različitih bolesti bila uspješna najvažnije je postaviti odgovarajuću dozu i primjerenu učestalost. Cilj ovog rada je, proučavanjem literature, prikazati pozitivne učinke kanabisa na zdravlje.

Ključne riječi:kanabis, pozitivni učinci, zdravlje

Osoba za razmjenu informacija:

Maja Batori, prvostupnik socijalnog rada

E mail: m. batori95@gmail.com

\section{UVOD}

Kanabinoidi su danas jedni od najraširenijih ilegalnih psihoaktivnih tvari. Aktivni su sastojci jednogodišnje biljke koja se zove indijska konoplja. Svrstava se među najstarije kultivirane biljke. Rod Cannabisčine biljke Cannabissativa,Cannabisindicai Cannabisruderaliste niz drugih iz njih nastalih varijeteta i biljnih formi. U biljci se nalazi više od 460 sastojaka među kojima se nalazi 60-ak spojeva kanabinoidne strukture. Aktivne tvari koje su prisutne u kanabisu su tetrahidrokanabinol (THC) koji ima analgetski učinak pa se koristi u liječenju boli. THC stimulira apetit te pojačava osjete mirisa i sluha i pomaže u suzbijanju mučnine i povraćanja. THC stimulira živčane stanice u mozgu te one izlučuju dopaminuzrokovajući euforiju. Također, THC utječe na to kako se informacije prenose u hipokampusu, dijelu mozga zaslužan za nastajanje sjećanja. Djelovanje THC-a započinje u roku od 10 do 30 minuta nakon upotrebe, a traje otprilike 2 sata (1).

Druga aktivna tvar je kanabidiol (CBD) koji sinergetički a THC-om poboljšava njegovo analgetičko i spazmolitičko djelovanje. CBD je najznačajniji u liječenju epilepsije i drugih napada. CBD se može zasebno koristiti u prevenciji dijabetesa, određenih vrsta raka i artritisa. Treći po zastupljenosti je kanabinol (CBN) koji nastaje kemijskom razgradnjom 
THC-a. Značaj ovih biljaka prisutan je desecima tisuća godina kao izuzetan dar čovječanstvu kroz svoje mnogobrojne odlike i široke mogućnosti primjene. Medicinska, poljoprivredna, prehrambena, građevinska, tekstilna te energentska svojstvenost od korijena pa sve do vrhova čini ovaj rod jednim od najraširenijih biljnih rodova na svijetu (2).

Medicinska konoplja poprilično se koristi u konvencionalnom liječenju za veći broj zdravstvenih problema. Propisuje sa za osobe koje su oboljele od glaukoma kako bi se smanjio tlak u oku i za oboljele od multipla skleroze radi zaustavljanja ili smanjivanja grčeva mišića. Istraživanja ukazuju da kanabinoidi pomažu pri ozdravljenju većeg broja bolesti današnjice, a neke od tih bolesti su AIDS, rak, dijabetes, Alzheimerova bolest, multipla skleroza. Medicinska konoplja se primjenjuje i u liječenju epilepsije, depresije i tjeskobe. Upotreba kanabisa u terapijske svrhe dostupna je u različitim oblicima. Pacijent uz konzultaciju sa liječnikom odabire oblik koji je najučinkovitiji za njega i njegovu bolest. Neke od metoda primjene kanabisa su pušenje, primjena kanabisa pomoću isparivača, tinkture i čajevi izrađeni od kanabisa, te dermalna primjena (3).

\section{Kanabinoidni receptori}

Kanabinoidi su aktivni sastojci jednogodišnje biljke po imenu indijska konoplja (lat. Canabissativa), među kojima je najvažniji tetrahidrokanabinol (THC). Receptori u mozgu i perifernom živčanom sustavu koje stimulira THC, kanabinoidni receptori, otkriveni su 1990. godine, a 1992. godine otkriven je endogeni kemijski spoj koji stimulira tu vrstu receptora - anandamid. Anandamid se veže na receptore mnogo slabije i kraće od samog THC-a. Funkciju endokanabinoidnog sustava istraživali su brojni znanstvenici te su zaključili da ima važnu ulogu u regulaciji imunosnog sustava, upalnih procesa, krvnog tlaka, tjelesne temperature, gastrointestinalne funkcije, analgezije i brojnih drugih tjelesnih procesa. Uloga ovog sustava je održavanje ravnoteže, odnosno homeostaze organizma. Receptori za THC i anandamid smješteni su u dijelovima mozga odgovornim za kretanje tijela, dakle, u malom mozgu, moždanoj kori te bazalnim ganglijima. Prisutnost receptora $\mathrm{u}$ malom mozgu i bazalnim ganglijima može biti odgovorna za njegovo djelovanje na grčeve mišića i smetnje u kretanju, dok receptori u kori mozga objašnjavaju djelovanje kanabisa na kognitivne funkcije (4).

Kanabis djeluje preko dva tipa receptora, kanabinoidnih receptora tipa 1 (CB1 receptori) i kanabinoidnih receptora tipa 2 (CB2 receptora). CB1 receptori primarno su smješteni u mozgu, u dijelovima koji kontroliraju pamćenje i kognitivne sposobnosti. Preko ovih receptora dolazi do psihoaktivnog učinka kanabisa. CB2 receptori smješteni su u ekstremitetima i u imunosnim tkivima, te ih zato nazivamo perifernim receptorima. Ovim receptorima dostupno je manje informacija jer su otkriveni kasnije od CB2 receptora (5).

\section{Povijest korištenja medicinske konoplje}

Mnogo dokaza govore da se kanabis koristio u kineskoj medicini tijekom vladavine Chen Nunga 5000 godina prije Krista. Drugi dokumenti, koji govore o korištenju kanabisa, datiraju do 2350 godina prije Krista. Ti dokumenti su zapravo kamene ploče iz egipatskog kraljevstva s kraja Pete Dinastije. U njima je napisano o medicinskim koristima konoplje kao protuupalne biljke. Grci i Rimljani su zapisali medicinske koristi kanabisa. U 9. stoljeću kanabis je bio više znan kao hašiš i puno se upotrebljavao kao lijek protiv boli. Početkom 10. st. počelo se pisati o nekim negativnim učincima hašiša. Tako je jedan arapski liječnik upozoravao na komplikacije prilikom upotrebe hašiša. Tvrdio je da miješanje hašiša s drugim psihoaktivnim tvarima može uzrokovati smrt. U europskoj literaturi, pri kraju 19.st. pojavili su se članci o upotrebi konoplje u liječenju bjesnoće, reumatskih bolesti, epilepsije i tetanusa. Nakon toga, medicinska upotreba kanabisa se raširila među mnogim europskim zemljama i u SAD-u (6).

$\mathrm{Na}$ vrhuncu popularnosti medicinske konoplje, postojali su mnogi medicinski pripravci koji su se koristili pri ublažavanju menstrualnih bolova, astme, kašlja, nesanice, bolova pri porodu, migrene itd. Početkom 20. st. počeli su se stvarati veliki problemi zbog promjenjive kvalitete tih medicinskih pripravaka te zbog problema pri uvozu lijekova 
$\mathrm{u}$ daleke zemlje. Događalo se da su neki bolesnici dobivali lijekove s malim postotkom konoplje, pri čemu ti lijekovi nisu mogli djelovati na njihova stanja, dok su drugi bolesnici dobivali lijekove s visokim postotkom konoplje te imali snažne nuspojave. Zbog svega toga, uvelike se smanjila upotreba konoplje u medicini te se njeno korištenje sve više zakonski ograničavalo (7).

Tijekom 60-ih godina, pojavili su se rekreativni korisnici marihuane. To su bili mladi ljudi i studenti većinom iz Velike Britanije, Novog Zelanda, Kanade i Australije. Tada su indijska konoplja te njeni pripravci proglašeni opasnim narkoticima od strane UN-a koji su na konferenciji 1961. g. prihvatili "Jedinstveni sporazum o opojnim drogama“. Tada se zanemarila medicinska korist konoplje te se sve više govorilo o opasnostima korištenja pripravaka od konoplje (8).

Liberalizacija i legalizacija medicinske konoplje, ponovno je započela prije tridesetak godina. Upotreba medicinske konoplje počela je češće zanimati stručnjake medicine jer se pokazalo da upotreba konoplje smanjuje simptome kemoterapije (9). Danas, države sve više legaliziraju upotrebu marihuane upravo zbog njenih pozitivnih učinaka. U Hrvatskoj je legalizirana upotreba pripravaka na bazi marihuane u medicinske svrhe. Ipak, marihuana se nije potpuno dekriminalizirala. „Ministarstvo zdravstva je izmjenama i dopunama Pravilnika o mjerilima za razvrstavanje lijekova te o propisivanju i izdavanju lijekova na recept (Narodne novine, br. 86/13, 90/13, 102/14, 107/15 i 72/16) omogućilo propisivanje gotovih lijekova i pripravaka na bazi konoplje u medicinske svrhe od strane liječnika specijalista za ublažavanje tegoba pacijenata oboljelih od multipla skleroze, karcinoma, epilepsije i AIDS-a, te ih je na taj način učinilo dostupnim pacijentima u kontroliranim uvjetima“ (10).

\section{Medicinska konoplja}

Sastojci koji su sadržani u konoplji posjeduju terapijska svojstva za velik broj ljudskih bolesti i fizičkih slabosti. Mlado lišće konoplje ima narkotička svojstva, a isto to lišće služi u terapijske svrhe za tretiranje većeg broja bolesti pod imenom medicinska konoplja (11).

Sircus pojašnjava kako se medicinska konoplja koristi u konvencionalnom liječenju za veći broj zdravstvenih problema. Propisuje za osobe koje su oboljele od glaukoma kako bi se smanjio tlak u oku i za oboljele od multipla skleroze radi zaustavljanja ili smanjivanja grčeva mišića kao i oboljelima od AIDS-a i raka kako bi im se smanjila mučnina i potaknuo apetit. Konoplja se primjenjuje i u liječenju epilepsije, depresije i tjeskobe. Istraživanja ukazuju da kanabinoidi pomažu pri ozdravljenju većeg broja bolesti današnjice, kao što su rak, dijabetes, autizam, Alzheimerova bolest (11).

U SAD-u konoplju mogu upotrebljavati ljudi oboljeli od težih bolesti, kako bi smanjili tjelesnu bol. U nekim europskim zemljama, primjerice $u$ Nizozemskoj, konoplja je dekriminalizirana. Države koje su odobrile njenu primjenu su više država u SAD-u, Kanada, Meksiko, Argentina, Portugal, Jamajka, Ekvador, Urugvaj, Peru, Sjeverna Koreja, Izrael, Češka, Slovačka, Poljska, Rumunjska, Španjolska, Belgija, Francuska, Njemačka, Italija, Austrija, Slovenija, Švicarska, Nizozemska, Švedska, Finska, Danska, Velika Britanija i Hrvatska (12).

Medicinski kanabis je pripravak s kanabinoidnim tvarima. Gazdek navodi da se za sada primjenjuju tri lijeka s kanabinoidnim tvarima:

- Dronabinol koji je sintetski izomer THC-a a postoji kao 2,5 mg, $5 \mathrm{mg}$ i $10 \mathrm{mg}$ dronabinol kapsule. Dostupan je u SAD-u, Kanadi i nekim zemljama EU-a. Koristi se za poboljšanje apetita kod anoreksije uzrokovane AIDS-om te kontrolu mučnine i povraćanja za vrijeme kemoterapije. Istraživanja također pokazuju da je učinkovit i u reduciranju neuropatske boli kod multipla skleroze.

- Nabilon je sintetski kanabinoid i $1 \mathrm{mg}$ nabilona odgovara 7-8 mg dronabinola. FDA (Foodand Drug Administration) ga je odobrio 1985. godine za ublažavanje mučnine i povraćanje kod kemoterapije karcinoma. Novija istraživanja pokazuju učinkovitost i kod neuropatske kronične boli.

- Nabiksimol je oromokuzni sprej koji sadržava ekstrakt biljke kanabis, odnosno kanabinoide THC i CBD u omjeru 1:1 (2,7 mg : 2,5 mg). Namijenjen 
je ponajprije za ublažavanje simptoma spastične boli kod multiple skleroze (12).

U Hrvatskoj, 15. listopada 2015. godine stupio je na snagu pravilnik Ministarstva zdravlja kojima se dopušta korištenje medicinskog kanabisa za oboljele od multiple skleroze, karcinoma, epilepsije i AIDS-a. Pravilnikom je propisano da se lijekovi koji sadrže THC, donabinol i nabilon mogu izdavati u ljekarnama isključivo na liječnički recept. Lijekove će propisivati izabrani doktori opće medicine po preporuci specijalista na neponovljivi recept. Lijekovi koji sadrže THC moći će se propisivati u količini potrebnoj za liječenje do najviše 30 dana, a ukupna količina propisanog THC-a ne smije biti veća od 0,75 grama.

\section{Medicinska primjena kanabisa}

Backes pojašnjava da medicinska konoplja može riješiti simptome različitih bolesti. Odgovarajuća doza i primjerena učestalost su bit uspješne upotrebe konoplje kao lijeka(13).

Postoji sve više znanstvenih dokaza o učinkovitosti kanabisa u liječenju različitih bolesti. Posljednjih godina, kliničke studije su pokazale da se kanabis i njegovi pripravci mogu koristiti za liječenje boli kod HIV-a/AIDS-a, kao terapije multipla skleroze i raznih drugih stanja(14).

\section{Utjecaj kanabinoida na ljude oboljele od Alzheimerove bolesti}

Alzheimerova bolest je bolest mozga vezana uz dob, a često se povezuje s kognitivnim propadanjem. Oblik demencije koji se s vremenom pogoršava, ometa pamćenje, razmišljanje i ponašanje. Sircus dodaje da oboljeli od Alzheimerove bolesti mogu iskusiti depresiju, pomutnju, a i gubitak apetita (11).

Dr. Kim D. Janda i njegove kolege s Instituta Scripps koristili su laboratorijske pokuse kako bi dokazali učinak THC-a koji čuva mozak od ključnog neurotransmitera acetilkolina. Pokusi su pokazali da THC sprječava tvorbu amiloidnihplakova koji su glavno obilježje Alzheimerove bolesti o štete koju ta bolest čini mozgu. Backes ističe da se biljna konoplja ponajprije primjenjuje da se osoba koja pati od Alzheimerove bolesti umiri, uspava te da joj se poveća apetit (13).

\section{Utjecaj kanabinoida na ljude oboljele od multipla skleroze}

Multipla skleroza je bolest središnjeg živčanog sustava koju karakteriziraju grčevi u mišićima i bol, tremor, oštećenje vida, slabost, gubitak kontrole mjehura te kognitivna i govorna oštećenja. Nije poznat lijek kojim bi se ova bolest mogla izliječiti. Smatra se da se ova bolest pojavljuje kao rezultat greške $\mathrm{u}$ imunološkom sustavu što uzrokuje upalu živaca u mozgu, moždanom deblu i kralježničnoj moždini. Ova bolest napada mijelinsku ovojnicu na živcima koja služi za prenošenje živčanih impulsa između živčanih stanica s posljedicom da se živčani impulsi mogu samo djelomično ili nikako prenositi. Postoje razna istraživanja djelovanja kanabinoida na simptome MS-a (15).

Istraživanje provedeno 2006. godine za cilj je imalo opisati učinke marihuane na multipla sklerozu, iz perspektive samih korisnika. $U$ istraživanju je sudjelovalo osam žena i šest muškaraca, koji su u individualnim intervjuima opisivali svoja iskustva $s$ primjenom marihuane. Većina je isticala opuštanost i ublažavanje specifičnih simptoma kao što su bol, spazam, tremor, mučnina, poremećaji u radu crijeva i mokraćnog mjehura. Ispitanici su naveli da su osjećali manji umor, da im se poboljšao apetit, kao i sposobnost kretanja. Ovakvo djelovanje marihuane za većinu je nastupala vrlo brzo, a trajanje je variralo od nekoliko sati pa sve do cijelog dana, vjerojatno zbog različite primijenjene doze. Dio ispitanika istaknuo je lakše utonuće u san, te smanjenu potrebu za konvencionalnim lijekovima (analgeticima, miorelaksansima...) (16).

Rezultati istraživanja baziraju se samo na subjektivnom osjećaju sudionika koji mogu zapravo biti euforični zbog uzimanja konoplje i mogu osjetiti samo smanjenje boli. Također, u sličnim istraživanjima, uvidjelo se da su placebo skupina sudionika također osjetili smanjenje simptoma MS-a što se pripisuje, zapravo, psihološkim utjecajima ovakvih istraživanja na ljude (15). Iz svih istraživanja o utjecaju kanabinoida na MS, može se zaključiti da, 
prema riječima pacijenata, kanabinoidi uzrokuju smanjenje boli i olakšanje u mišićima. Potrebno je više istraživanja koji će odgovoriti na pitanje da li su ta olakšanja uzrokom stvarnog popuštanja napetosti mišića ili kanabinoidi više pružaju psihološki osjećaj olakšanja.

\section{Utjecaj kanabinoida na ljude oboljele od epilepsije}

Epilepsija je kronična, često progresivna neurološka bolest koju karakteriziraju napadaji. Može se pojaviti u različitim oblicima, izazivajući napade koji uključuju agresivno grčenje mišića, gubitak koordinacije, gubitak svijesti, a u ekstremnim slučajevima može doći do kome i smrti. Ova bolest može biti uzrokovana genetskim faktorima, različitim traumama, te nekim drugim bolestima (14).

Istraživanja o utjecaju kanabionida kod pacijenata oboljelih od epilepsije su posljednjih godina porasla. Najviše se istražuje utjecaj kanabidiola (CBD) na smanjenje napada kod epilepsije te drugih bolesti . CBD, za razliku od THC-a uzrokuje znatno manje psiholoških posljedica te se najčešće ne zloupotrebljava. Zbog svega toga, tijekom godina, sve više se koriste ekstrakti obogaćeni CBD-om u liječenju bolesti koji uzrokuju napade. Pogotovo, ti se ekstrakti koriste u liječenju djece. Iako postoji poboljšanje u kontroli napada, koristi u spavanju i ponašanju, interpretacija podataka je otežana zbog nekontrolirane prirode promatranja utjecaja CBD-a. S druge strane, sve je više uspješnih istraživanja utjecaja CBD-a. Primjerice, Devinsky i sur. 2018. godine proveli su istraživanje prilikom kojeg su kombinirali lijekove protiv napadaja i CBD. U istraživanju je sudjelovalo 225 pacijenata, raspona od 2 do 55 godina. Svi su ispitanici patili od Lennox - Gastaut sindroma. Pacijenti su podijeljeni u tri grupe. Prva grupa, primila je $10 \mathrm{mg}$, druga grupa $20 \mathrm{mg}$ CBD-a, dok je treća grupa primala placebo. Rezultati istraživanja, pokazali su da su se napadi najviše smanjili u grupi koja je primala 20 mg CBD-a. U toj grupi, najviše je bilo nuspojava kao što su: pospanost, smanjen apetit i diareja. Ovo istraživanje je pomoglo otvoriti nova vrata upotrebi medicinske konoplje. Nedugo nakon objave istraživanja, novi lijek Epidiolex koji sadrži
CBD odobren je od strane FDA u lipnju 2018. godine (17).

\section{Utjecaj kanabinoida u borbi protiv migrene}

Migrena je jaka glavobolja koja traje satima ili danima, a praćena je vizualnim smetnjama ili mučninom i povraćanjem, ili i jednim i drugim. Napadaji se najčešće ponavljaju. Može ju pokrenuti stres, određena vrsta hrane i određeni tipovi osjetnih podražaja, kao što su, jako svjetlo, glasna buka, jaki mirisi (18).

Lijekovi od konoplje se koriste 1500 godina kao terapija za migrenu i ostale glavobolje. Dr. Ethan Russo je pretpostavio da neki oblici migrene mogu biti posljedica nedostataka endokanabinoida. Backes ističe da je konoplja učinkovita preventiva i smanjuje učestalost migrene kod velikog broja pacijenata. Također je uspješna za uobičajene tenzijske glavobolje. Kanabinoidi modeliraju i djeluju u mnogim smjerovima svojstvenim migrenama, na način na koji djeluju konvencionalni lijekovi, što upućuje na potencijalne sinergijske i slične pogodnosti. Do danas su ograničeni dokazi istraživanja koja ukazuju na ulogu kanabinoida i kanabisa kod liječenja migrena, te je potrebno poticanje novih istraživanja što bi liječnicima omogućilo da propisuju kanabis ili lijekove na bazi kanabisa za liječenje migrena (13).

\section{Utjecaj kanabinoida na simptome povezane s HIV/AIDS}

Tijekom infekcije, virus HIV-a napada T4 limfocite uništavajući CD4 stanice. Uništavanje tih T4 stanica zaslužno je za napredak bolesti. Kao i u prijašnjim opisima djelovanja kanabinoida na različita stanja, ovdje, također, imamo razna istraživanja utjecaja kanabinoida na virus HIV. Smatra se da kanabinoidi smanjuju napredak bolesti. Istraživanje provedeno 2014. godine, pokazalo je da je THC pospješio stvaranje CD4 i CD8 stanica u imunosnom sustavu majmuna. Druga istraživanja pokazuju da se korištenjem kanabisa smanjuje, od 30 do 60 posto broj inficiranih stanica (19).

Danas postoje i mnogi članci koji govore o iskustvu ljudi koji su počeli koristiti marihuanu. Neki od njih su koristili lijek Marinol koji sadrži sintetički 
THC. On je legalan lijek te se često propisuje. Ali, on sadrži mnoge nuspojave. Jedna od tih nuspojava je velika pospanost što uvelike narušava kvalitetu života čovjeka. Zbog toga se sve više i više javlja korisnika marihuane. Pušenjem marihuane oboljeli od virusa HIV-a mogu više kontrolirati nuspojave te im se simptomi, kao, primjerice, manjak apetita, mogu smanjiti nakon samo par dimova iz marihuana cigarete. Poznate su riječi jednog liječnika koji je rekao da marihuana, kod teško oboljelih pacijenata, može napraviti razliku između života i smrti, dok, kod smrtno bolesnih bolesnika, može napraviti razliku između umiranja u miru ili umiranja u konstantnoj i velikoj agoniji (20).

\section{Utjecaj kanabinoida na stres}

Često se navodi da marihuana povoljno djeluje na simptome stresa. Prijašnjih godina su se zakoni za medicinsku upotrebu kanabisa drastično promijenili. Ipak, još uvijek je veoma teško dobiti dozvolu za proučavanje djelovanja kanabisa (21).

Grupa istraživača sa Sveučilišta Illinois u Chicagu i sa Sveučilišta Chicago, istraživali su djelovanje THC-a na stres kod zdravih individualaca. Odlučili su iskoristiti tri vrste kapsula s različitim količinama THC-a. Iskoristili su četrdeset i dvoje ljudi koje su podijelili u tri grupe. Prva grupa je bila grupa od trinaest ljudi koji su primili placebo kapsule s $0 \mathrm{mg}$ THC-a. Druga grupa je bila grupa od četrnaest ljudi koji su primili kapsule sa 7.5 mg THC-a. Treća grupa od petnaest ljudi je primila kapsulu sa $12.5 \mathrm{mg}$ THC-a. Ni istraživači ni sudionici nisu znali tko je koju kapsulu dobio. Kapsule su se podijelile 2.5 sati prije različitih zadataka u kojima su sudionici trebali sudjelovati. Također, sudionici su sudjelovali u istraživanju po 4 sata u pet dana razlike. To znači da je svaki sudionik primio dvije kapsule. Prije i poslije tih zadataka mjerili su se subjektivno raspoloženje i utjecaj kapsule, vitalni znakovi te količina kortizola (hormona stresa). Zadaci koje su sudionici trebali proći su: intervju za posao, intervju s laboratorijskim tehničarom gdje su trebali pričati 5 min o svojoj omiljenoj knjizi ili filmu te 5 min igrati solitaire. Zadnji zadatak, koji su sudionici trebali proći bio je matematički zadatak koji se rješavao pet minuta.
Rezultati istraživanja su pokazali da nema razlike u vitalnim znakovima te nivoima kortizola između tri grupe. Dalje, grupa koja je primila $7.5 \mathrm{mg}$ THC-a prijavili su manju količinu stresa nakon zadatka nego placebo grupa. Zanimljivost je da je grupa, koja je primila $12.5 \mathrm{mg}$ THC-a prijavila negativno raspoloženje prije i tijekom zadataka. Također, ta grupa je navela da su zadaci bili izazovni. Na kraju, grupa istraživača su zaključili da mala doza THC-a smanjuje simptome stresa dok veća doza THC-a može, ne nužno, potaknuti negativno raspoloženje (22).

\section{Utjecaj kanabinoida na posljedice raka i kemoterapije}

Kemoterapija je oblik liječenja raka. Ona se daje kao jedan lijek ili kao kombinacija lijekova koji uništavaju ili kontroliraju rast stanica raka. Osim što kemoterapija djeluje na stanice raka, ona također djeluje i na zdrave stanice koje su najčešće smještene $u$ koštanoj srži, probavnom sustavu i folikulama kose. Od nekih negativnih posljedica kemoterapije najčešći su: anemija, infekcije, krvarenja zbog uništenja zdravih stanica u koštanoj srži. Posljedice djelovanja kemoterapije na zdrave stanice u probavnom sustavu su: mučnina, povraćanje i gubitak apetita, čirevi u ustima i bolovi pri gutanju, proljev i učestali poticaj na veliku nuždu, zatvor, promjene u osjećaju okusa (23).

Danas se sve više govori o liječenju malignih bolesti pomoću kanabisa. Javlja se problem što se to ne može dokazati jer nema dovoljno istraživanja koji bi potkrijepili tu tvrdnju. Istraživanja su se jedino vršili na miševima i štakorima te je potrebno više istraživanja da potkrijepe tvrdnju da kanabis liječi rak. Lijekovi od konoplje uspješno se primjenjuju protiv mučnine i povraćanja, koji su posljedica kemoterapije. Također su pojačali učinak opioidnih lijekova protiv boli izazvane karcinomom. Potiču tek, spavanje, smanjuju tjeskobu i depresiju te mogu oraspoložiti pacijente koji se liječe od karcinoma, a to sve poboljšava kvalitetu života oboljelih od karcinoma. Kemoterapija uzrokuje mučninu i povraćanje, a pokazalo se da lijekovi od konoplje ublažavaju povraćanje uzrokovano kemoterapijom. Mentalni i 
fizički aspekt psihoaktivnosti medicinske konoplje povećava njezinu učinkovitost u ublažavanju mučnine izazvane kemoterapijom. Baceks dodaje i to da endokanabinoidni sustav regulira tek. Tradicionalni antiemetici sprječavaju povraćanje i mučninu, ali ne povećavaju tek, a lijekovi od konoplje mogu učiniti i jedno i drugo (23).

Lijekovi na bazi konoplje prilično učinkovito smanjuju, a ponekad i sprječavaju neke vrste bolova uzrokovane karcinomom. Prvi eksperiment gdje su dokumentirani protutumorski učinci konoplje je iz 1974. godine s Medicinskog fakulteta Virdžinije uz podršku vlade $\mathrm{SAD}$-a. Rezultati istraživanja pokazali su da je psihoaktivni sastojak konoplje THC usporio rast raka pluća, raka dojke i od virusa potaknute leukemije kod laboratorijskih miševa i produžio njihov život najviše za $36 \%$ (11).

Bello navodi kako su u jednom važnom istraživanju marihuane i raka dojke ekstremno agresivne stanice raka (koje obično prerastu čitav organ u kojem su se razvile, nakon čega se prošire po cijelom tijelu) prestale s diobama nakon davanja samo jednog od šezdesetak kanabinoida marihuane. Dakle, jedan spoj marihuane, CBD, u stanicama raka dojke zaustavio je ekspresiju određenog opasnog gena prije nego što se on reproducirao (24).

\section{METODE PRIMJENE MEDICINSKOG KANABISA}

Liječenje kanabisom nije za svakog pacijenta isto. Najvažniji faktor u liječenju jest odnos bolesti s ljekovitim sastojcima u kanabisu. Trenutno u biljnom svijetu kanabisa postoji na tisuće različitih sorti koje svojim sastavom pružaju točno ono što je pacijentu u borbi s njegovom bolešću potrebno. $U$ državama u kojima je upotreba kanabisa u terapijske svrhe dozvoljena zakonom, kanabis je dostupan u različitim oblicima, kao što su pušenje, primjena kanabisa pomoću isparivača, tinkture i čajevi izrađeni od kanabisa, te dermalna primjena. Pacijentu se ostavlja opcija da sam ili uz konzultaciju s liječnikom odabere oblik koji je najučinkovitiji za njega i njegovu bolest (13).

\section{Pušenje kanabisa}

Pušenje je najčešća metoda primjene kanabisa. Brzo podiže razine THC-a u krvi, što se može izmjeriti u pet sekundi nakon udisanja. Tada se postižu najviše razine kanabinoida u krvi. Radi brzog načina uzimanja, pacijenti mogu jednostavno i brzo naučiti kontrolirati dozu unesenu pušenjem tako da jednostavno doziraju dozu udisaj po udisaj, te čekaju nekoliko minuta između svakog udisaja (13).

Osobama koje primjenjuju marihuanu pušenjem, liječnici savjetuju da koriste što kvalitetniju marihuanu, s većim udjelom THC-a, kako bi bila potrebna kraća primjena do postizanja učinkovitosti. Također, stručnjaci upozoravaju da je dugo zadržavanje dima vrlo štetno za pluća, a neće dovesti do bržeg, jačeg ili dugotrajnijeg djelovanja marihuane (25). Marihuana se može pušiti i pomoću lule i na takav način izbjegava se inhalacija kemikalija prisutnih u papiru za izradu cigareta marihuane, tzv. jointova, a dim je hladniji i manje iritira grlo i respiratorni sustav. Primjenom lule bolja je apsorpcija aktivnih sastavnica marihuane nego primjenom jointa (26).

\section{Primjena kanabisa pomoću isparivača}

Isparivači zagrijavaju biljnu konoplju do temperature na kojoj aktivni sastojci isparavaju i stvaraju paru koja se može udahnuti. Prednost upotrebe isparivača je ta što sva para ostaje zadržana unutar same kapsule isparivača, što sprječava širenje terapijski aktivnih spojeva u okolni prostor (26).

\section{Tinkture i čajevi izrađeni od kanabisa}

Tinkture koriste otapala, poput etanola kako bi razgradile aktivne sastojke iz ljekovitih biljaka poput kanabisa. Namakanje kanabisa u snažnom etanolu temelj je većine tinktura od kanabisa. Mogu se primjenjivati kao dodatak hrani i pićima, primjenjivati sublingvalno i topikalno (preko kože). Njihova izrada je jeftina i jednostavna, a kako se alkoholna baza brzo apsorbira, učinak nastupa brzo. Nema štetnih učinaka kao kod pušenja marihuane, a učinak im traje duže. Lišće, cvjetovi i stabljike biljke korist se i za pripremu čajeva. Postupak je sličan pripremi uobičajenih čajeva, osim što je u vrelu vodu nužno dodati ulje ili maslac kako bi se aktivne komponente, 
netopljive u vodi, oslobodile iz biljke. Jačina učinka čajeva može varirati od vrlo slabih do iznimno jakih, ovisno o količini upotrijebljenih sastojaka (26).

\section{Dermalna primjena kanabisa}

U kožnim stanicama točnije neuronima i mastocitima pronađeni su endokanabinoidni receptori. Balzami, kreme, losioni i masti na bazi marihuane izrađuju se pomoću ulja marihuane, a apliciraju se direktno na kožu. Mogu biti vrlo učinkoviti kao analgetici i antiinflamatorici. Indikacije za koje se preporučuju ovi pripravci su otekline, opekline, bolovi u mišićima, osipi, artritis, kao i postherpetička neuralgija. Dokazano je da masti i kreme koji sadrže aktivne komponente konoplje imaju antibakterijsko djelovanje te ubrzavaju zacjeljivanje rana. Kanabinoidi se mogu apsorbirati kroz kožu i pokazalo se $\mathrm{da}$ imaju protuupalni učinak $\mathrm{u}$ istraživanjima provedenim na životinjama. Postoji veliki broj kanabinoidnih receptora u koži pa upijanje može pomoći u terapiji nekih kožnih bolesti poput apsorijaze (27).

\section{ZAKLJUČAK}

Pregledom i analizom stručne literature može se zaključiti da se kanabis već tisućama godina koristi kao lijek za ublažavanje raznih simptoma bolesti. Danas se vode brojne rasprave u pogledu korisnosti uzimanja kanabinoida. Brojna istraživanja su pokazala kako medicinski kanabis učinkovito ublažava simptome raznih bolesti kao što su Alzheimerova bolest, HIV/AIDS, epilepsija, migrena i karcinom.

Veliki broj populacije smatra da je kanabis štetan i da ostavlja negativne posljedice na čovjeka. Razlog tomu je što kanabis pripada u kategoriju „lakih droga" koja je ilegalna i samim time se etiketira kao nešto loše. Još jedan od razloga je neznanje društva, većina ljudi zapravo ni ne zna koliko kanabis pozitivno djeluje i ublažava razne simptome bolesti. Širenjem znanja o ljekovitošću ove biljke obogaćujemo odnos čovjeka s lijekovima iz prirode. Neke države zakonski su odobrile uporabu kanabisa u medicinske svrhe za određene bolesti koje su propisane pravilnikom. Radi iznošenja neprovjerenih tvrdnji o štetnosti kanabisa i o njegovoj navodnoj ovisnosti, kanabis se češće spominje u negativnom kontekstu i zbog toga veliki broj ljudi sumnja u njegove terapijske mogućnosti.

Zbog medicinske koristi upotrebe kanabisa potrebno je u zakonodavstvu zemalja odrediti na koji način se može koristiti znanstvena učinkovitost indijske konoplje, pritom, vodeći računa o bilo kakvoj zlouporabi korištenja marihuane u medicinske svrhe.

\section{LITERATURA:}

1. Bradford A. What is THC?; 2017. [Internet.]. [Posjećeno 20.08.2018.]. Dostupno na: https:// www.livescience.com/24553-what-is-thc.html

2. Holland K. CBD vs. THC: What's theDifference?; 2018. [Internet.]. [Posjećeno 29.08.2018.]. Dostupno na: https://www.healthline.com/health/ cbd-vs-thc.

3. Babić D. i sur. Psihoaktivne tvari: duševni poremećaji ponašanja uzrokovani uporabom psihoaktivnih tvari. Mostar: Sveučilište u Mostaru; 2016.

4. Barry C. i Dennis P. Marihuana. Zagreb: CELEBER; 2004. Duraković, N. Što je kemoterapija?; 2006. [Internet]. [Posjećeno 20.08.2018.]. Dostupno na: https://www.plivazdravlje.hr/aktualno/ clanak/10158/Sto-je-kemoterapija.html\#13241

5. Hyde W. What is Cannabisruderalis?; 2015.[Internet]. [Posjećeno 20.8.2018.]. Dostupno na: www.leafscience.com

6. Farag S. i Kayser O. MedicinalandAromaticPlantsofthe World: Scientific, Production, CommercialandUtilizationAspects. Nizozemska: SpringerNetherlands; 2015.

7. Hazekamp A. Cannabis; Extractingthe medicine. Leiden: ProefschriftUniversiteitLeiden; 2007.

8. Hill B. Cannabis: A JourneyThroughtheAges; 2015. [Internet.]. [Posjećeno 17.08.2018.]. Dostupno na: https://www.ancient-origins.net/ history/cannabis-journey-through-ages-003084

9. Janet E. i sur. Marijuanaand Medicine-AssessingtheScience Base. Washington, D.C.:Institute of Medicine; 1999.

10. Vlada Republike Hrvatske. Prijedlog zakona o izmjenama i dopunama Zakona o suzbijanju zlo- 
uporabe droga-mišljenje Vlade. Zagreb: Vlada Republike Hrvatske; 2017.

11. Sircus M. Medicalmarijuana: Treatmentsof: Cancer, RadiationExposure, NeurologicalConditions, Autism, Pain, StressandEmotionalUpset. Lulu.com; 2014.

12. Gazdek D. Marihuana u medicinske svrhe - javnozdravstveni aspekt.Liječnički vjesnik, Vol.136 No.7-8. [Internet]. [Posjećeno 29.8.2018.]. Dostupno na:https://hrcak.srce.hr/index.php?show=clanak\&id_clanak_jezik=254712

13. Backes M. Marihuana kao lijek: Praktični vodič za upotrebu marihuane u medicinske svrhe.Zagreb: Mozaik knjiga; 2016.

14. Gieringer D., Rosenthal E., Cartet GT. MarijuanaMedicalHandbook: practicalguide to thetherapeuticusesofmarijuana.Quicktradingcompany; 2008.

15. Mack A. i Joy J. Marijuana as Medicine? TheScienceBeyondtheControversy. Washington (DC): National AcademiesPress; 2000.

16. Page SA, Verhoef MJ. Medicinalmarijuana use: experienceswithmultipleselerosist. CanFamPhysiciam; 2006.

17. Patel A. i Kiriakopoulos E. MedicalMarijuanaandEpilepsy; 2018. [Internet.]. [Posjećeno 26.08.2018.] Dostupno na: https://www.epilepsy.com/learn/treating-seizures-and-epilepsy/ other-treatment-approaches/medical-marijuana-and-epilepsy

18. Grinspoon L. i B. Bakalar J. Marihuana zabranjeni lijek.Zagreb: Sara93; 1997.
19. Wraight J. iSelbovitz M. CouldCannabisTreat HIV?; 2015. [Internet.]. [posjećeno 20.08.2018.]. Dostupno na: https://www.hivplusmag.com/treatment/2015/02/24/could-cannabis-treat-hiv

20. Rahn B. Cannabisand HIV/AIDS; 2014. [Internet.]. [Posjećeno 4.9.2018.]. Dostupno na: https://www.leafly.com/news/health/cannabis-and-hivaids

21. Newman, T. (2017).Cannabisdoesrelievestress, but only at lowdoses. Preuzeto s https://www. medicalnewstoday.com/articles/317777.php

22. Childs, E., Lutz, J., Wit, H. (2017). Drug andAlcoholDependence- Dose-relatedeffectsof delta-9-THC on emotionalresponses to acutepsychosocialstress: TheUniversityof Chicago

23. AbramsD.I. Integratingcannabisintoclinicalcancer care; 2016. [Internet]. [Posjećeno 10.9.2018.]. Dostupno na: https://www.ncbi.nlm.nih.gov/ pmc/articles/PMC4791148/

24. Bello J. Liječenje raka marihuanom:Holističko zdravlje, disanje i marihuana.Zagreb: TELEdisk d.o.o.; 2014.

25. United patientsgroup. Ways to consumemarijuana. [Internet]. [Posjećeno 2.9.2018.]. Dostupno na:www.unitedpatientsgroup.com

26. Potter B. i Poy D. Thehealingmagicofcannabis. Roninpublishing, Oakland; 1998.

27. Grotenhermen F. i Leson G. Reassessingthe Drug Potential od IndustrialHemp. Berkeley, CA: LesonEnvironmentalConsulting; 2002. [Posjećeno 4.7.2018.]. Dostupno na: http://www.nova-institut.de/pdf/02- 04_Drug_Potential_of_Fibre_ Hem.pdf 


\title{
POSITIVE HEALTH EFFECTS OF CANNABIS
}

\author{
Maja Batori ${ }^{1}$, Ana Žerovnik ${ }^{1}$, Katarina Barać ${ }^{1,3}$, Dragan Babić ${ }^{1,2,3}$ \\ Faculty of Humanities and Social Sciences, University of Mostar ${ }^{1}$ \\ Faculty of Health Studies, University of Mostar ${ }^{2}$ \\ Clinic for Psychiatry, University Clinical Hospital Mostar ${ }^{3}$ \\ 88000 Mostar, Bosnia and Herzegovina
}

\begin{abstract}
Cannabinoids are the active ingredients of an annual plant called Indian Hemp (Latin Cannabissativa). Cannabis (marijuana or hemp) is one of the oldest and the most widespread plants known to man. It grows as weeds and is cultivated in different countries and climates all over the world. The chemical substances responsible for intoxication and medical efficacy are found in the sticky golden resin that covers the flowers of female plants. The cannabis plant contains more than 460 known ingredients among which more than 60 of them have a 21-carbon structure typical for cannabinoids. Cannabis is originally from Central Asia where it was cultivated ten thousand years ago and in China it was cultivated 4000 B.C. Cannabis is the most widespread and easily available illegal psychoactive substance for young people and is often classified as a "soft drug". According to international classifications cannabinoids fall within the group of psychoactive substances that can cause various mental and other health disorders. On the other hand, it has been proven that cannabis can also have positive effects on human health. Medical cannabis contains ingredients that have therapeutic properties for a large number of human diseases and physical weaknesses. Cannabis is prescribed to people suffering from multiple sclerosis to stop or reduce muscle spasms, it is also prescribed to those suffering from AIDS and cancer to reduce nausea and stimulate the appetite. It is also used in the treatment of epilepsy, depression, anxiety, and Alzheimer's disease. In order to successfully treat diseases with cannabis it is of most importance to set the appropriate dose and frequency of use. The objective of this work is to represent the positive health effects of cannabis by studying the relevant literature.
\end{abstract}

Key words: cannabis, positive effects, health

Correspondence:

Maja Batori, Bachelor of Social Work

Email: m.batori95@gmail.com 